\title{
Effects of health education on HIV/AIDS related knowledge among first year university students in China
}

\author{
Yan Liu ${ }^{1}, \mathrm{Li} \mathrm{Lu}{ }^{2}$, Yuan Yuan Wang ${ }^{3}$, Meredith R Wilkinson ${ }^{3}$, Yan-Ming Ren ${ }^{1}$, \\ Chao-Cai Wang ${ }^{4}$, Fa-Bin Zhang ${ }^{1}$, Jie Gao ${ }^{5}$, Shou Liu ${ }^{1}$
}

1. Department of Public Health, Medical College, Qinghai University, Xining, Qinghai, China.

2. Team IETO, Bordeaux Population Health Research Center, UMR U1219, INSERM, Université de Bordeaux, Bordeaux, France.

3. Department of Psychology, Faculty of Health and Life Sciences, De Montfort University, Leicester, UK.

4. Qinghai Center for Disease Prevention and control, Xining, Qinghai, China.

5. Department of Clinical Medicine, Qinghai Institute of Health Sciences, Xining, Qinghai, China.

\begin{abstract}
Background: The number of new HIV infections has increased and implementation of school-based health education programs on AIDS have been advocated for a long time.

Objective: This study aimed to explore the effectiveness of an intervention of HIV/AIDS on the knowledge of HIV/ AIDS prevention and control among first year university students.

Methods: An awareness questionnaire was adopted to assess awareness and knowledge of HIV/AIDS pre- and post-health education among first year university students in Qinghai, China. Independent sample t-test, chi-square test, and multiple logistic regression analyses were used.

Results: A total of 2,165 and 2,062 first year university students were respectively recruited pre- and post- HIV/AIDS health education. The awareness rate increased significantly after the health education intervention (from $48.59 \%, 95 \% \mathrm{CI}$ : 46.47\%-50.72\% to 76.24\%, 95\%CI: 74.35\%-78.06\%). Students from Hui and Tibetan ethnicities, and those holding prejudices against AIDS patients were less knowledgeable than their counterparts regarding HIV/AIDS related knowledge, whereas urban-dwellers and those with higher paternal education were positively associated with awareness of HIV/AIDS related knowledge $(\mathrm{p}<0.05)$.

Conclusion: HIV/AIDS awareness among first year university students improved greatly after receiving an education intervention, which underscores its utility as part of the approaches of HIV/AIDS control and prevention.

Keywords: HIV/AIDS knowledge; awareness; health education; university students; China.

DOI: https://dx.doi.org/10.4314/ahs.v20i4.10

Cite as: Liu Y, Lu L, Wang YY, Wilkinson MR, Ren Y-M, Wang C-C, et al. Effects of health education on HIV I AIDS related knowledge among first year university students in China. Afri Health Sci. 2020;20(4):1582-90. https:/ / dx.doi.org/ 10.4314/ ahs.v20i4.10
\end{abstract}

\section{Introduction}

The human immunodeficiency virus and the acquired immunodeficiency syndrome (HIV/AIDS) are glob-

\section{Corresponding author:}

$\mathrm{Li} \mathrm{Lu}$,

Université de Bordeaux,

Bordeaux, France;

Email address: liser@outlook.com

or

Shou Liu,

Department of Public Health,

Medical College, Qinghai University, China;

Email address: liushou2004@aliyun.com al public health issues and the leading causes of years lived with disability (YLDs) in many countries, such as South Africa, Lesotho and Swaziland, etc ${ }^{1}$. The World Health Organisation (WHO) reported that there were 37.9 million people living with HIV worldwide at the end of $2018^{2}$, and that people living with HIV/AIDS in China increased from 385,817 in 2012 to 789,617 in $2018^{3}$. There are multiple ways in which HIV can be contracted, such as through the sharing of bodily fluids which contain the virus, notably blood and semen, which could be prevented and avoided.

The number of new HIV infections has increased in recent years, and sexual transmission was responsible for $90 \%$ of the infections ${ }^{3}$. As a sexually active population, university students are at a high risk of con- 
tracting sexually-transmitted diseases (STDs), such as HIV/AIDS ${ }^{4,5}$. The figure of sexual behavior among university students varied greatly among studies and different regions. The lifetime prevalence of risky sexual behavior among college students was 40.8\% in Ethiopia ${ }^{6}$, one year prevalence was $72.2 \%$ in $\mathrm{Zambia}^{7}$. A survey including 19,123 Chinese college students found that only $24.8 \%$ of sexually active college students reported using a condom for every sexual encounter ${ }^{8}$. The high-risk sexual behavior among college students with regards to STDs is a matter of concern in public health 9,10 . The discriminatory attitudes to individuals who have HIV were also frequently reported, HIV-related stigma within health contexts is a broad social phenomenon which exists in diverse social spheres ${ }^{11}$.

Implementation of school-based health education programs on AIDS have been advocated for a long time ${ }^{12-14}$ and students also have claimed positive attitude on sexual health education ${ }^{15,16}$. Previous intervention studies have found a positive correlation between pro-active health behaviour and fact based health education ${ }^{17,18}$. Specifically, one systematic review revealed that educational interventions have been successful at reducing stigma ${ }^{19}$. Previous studies have indicated that making people more aware of HIV/AIDS leads to more positive attitudes towards HIV/AIDS patients ${ }^{20,21}$. In addition, individuals can engage in more preventive behaviours and reduce the risk of contracting HIV (more specifically, sexually transmitted diseases) by increasing knowledge 22,23. Qinghai province of China has diverse population composition (such as Han, Tibetan, Hui, Salar, etc.), cultures, religions and languages. For example, Tibetans all have belief in Tibetan Buddhism, religion beliefs could affect various aspects of adolescents' social and daily life and students' attitudes on sexual behaviors ${ }^{24,25}$. Besides, some first year university students came from other parts of China, the educational backgrounds could be different from those who have lived in Qinghai since birth. However, sexual behaviors and related issues and health programs among university students were under-researched in Qinghai ${ }^{26}$.

Therefore, this study aimed to explore the awareness and knowledge regarding HIV/AIDS prevention and control among first year university students in Qinghai, its key associated factors and the effects of health education. Based on previous studies ${ }^{27,28}$, we hypothesized that awareness and knowledge would be generally improved after health education.

\section{Methods}

\section{Study design, subjects and data collection}

A 'pre-post' intervention study was conducted among first year university students during their military training at Qinghai University, China. There are 12 universities and colleges in Qinghai Province, and Qinghai University is the only university in Qinghai province listed in the national "211 Project". It was selected as the pilot institution in Qinghai to conduct the pilot HIV / AIDS prevention and controlling intervention program launched by China's Ministry of Education. Cluster sampling was used to collect data before and after the courses. The pre-established questionnaire was sent out to the students who would attend the health education lectures (approximately all first year students attended the lectures) and collected by trained investigators on $31^{\text {st }}$ August, 2016 prior to the health education intervention. The same questionnaire was then sent out after students taking a one-hour health education lecture, which was delivered by doctors and associate chief physicians from the Department of Infectious Diseases of Qinghai Center for Disease Prevention and Control, from $1^{\text {st }}$ to $4^{\text {th }}$ September. In order to specifically benefit both sexes, the health education lectures were given separately among male and female students in different classrooms. All students were informed about the principle of anonymity and voluntary nature of the survey. A total of 2,165 and 2,062 students were involved preand post- the health education course, respectively and included students from different ethnic groups. The study protocol was approved by The Ethic Committee of Medical College of Qinghai University.

\section{Assessment tools}

Socio-demographic characteristics, such as age, gender, ethnic groups (Han/ Hui/ Tibetan/ others), where students lived for the longest time before they entered university (village, township/ county / city), single parent family (yes/no), paternal and maternal education level (primary school or below/junior/ senior middle school/ above senior middle school), relationship status (previously in a relationship/ in a relationship/ not in a relationship) and attitudes towards HIV/ AIDS patients (sympathetic and helpful/ indifferent / fearful and avoiding) were included in the questionnaire.

The "Awareness questionnaire of knowledge on HIV / AIDS prevention and control - young student version " was used to assess the status of first year students' knowledge and awareness on the knowledge on HIV/ AIDS prevention and control ${ }^{19}$. It was developed and 
recommended by the Chinese Center for Disease Control and Prevention in 2016 and has been applied in other Chinese studies ${ }^{29}$. The questionnaire contains eight questions with the response being "yes", "no" or "have no idea", and the respondent would be considered as "aware" if they answered at least 6 out of the 8 questions correctly, otherwise "unaware". Table 2 presents the questions which were asked.

\section{Statistical analysis}

Distribution of continuous data was examined using the Shapiro-Wilk test. Categorical and continuous variables were presented as number $(\mathrm{N})$ and frequencies $(\%)$, and mean and standard deviation (SD), respectively. Chi-square $\left(\mathrm{X}^{2}\right)$ test and independent sample t-test were appropriately used to explore the independent correlations between socio-demographic characteristics and awareness rate of HIV/AIDS pre- and posthealth education. Logistic regression models were built by setting "aware or not" as the dependent variable and other variables as independent variables to explore their correlations with awareness pre- and post-health education. Data analyses was conducted using STATA version 12.0 (STATA Corporation, College Station, Texas, USA) at the significance level of 0.05 (two-tailed).

\section{Results}

A total of 3,840 first year students at the Qinghai University were given the questionnaire, of whom 2,165 (response rate: 56.4\%) and 2,062 (response rate: 53.7\%) returned the questionnaires pre- and post- the health education course, respectively. Socio-demographic characteristics regarding to awareness of knowledge on HIV/AIDS prevention and control among first year university students pre- and post- health education are shown in Table 1. As shown in Table 2, awareness rate increased significantly after receiving health education for the whole prevalence (pre-health education: 48.59\%, 95\%CI: 46.47\%-50.72\%; post-health education: $76.24 \%, 95 \% \mathrm{CI}: 74.35 \%-78.06 \%$; $<<0.001)$ and also for each question.

Table 1 Socio-demographic characteristics regarding to HIVIAIDS awareness among first year students pre- and post- health education

\begin{tabular}{|c|c|c|c|c|c|c|c|c|c|c|c|}
\hline \multirow{3}{*}{ Variables } & & \multicolumn{4}{|c|}{$\begin{array}{l}\text { Pre- Health education } \\
\qquad(\mathrm{N}=2,165)\end{array}$} & \multirow{3}{*}{$\begin{array}{l}t / X^{2} \\
(p)\end{array}$} & \multicolumn{4}{|c|}{$\begin{array}{l}\text { Post- Health education } \\
\qquad(\mathrm{N}=2,062)\end{array}$} & \multirow{3}{*}{$\begin{array}{c}t / X^{2} \\
(p)\end{array}$} \\
\hline & & \multicolumn{2}{|c|}{ Unaware } & \multicolumn{2}{|c|}{ Aware } & & \multicolumn{2}{|c|}{ Unaware } & \multicolumn{2}{|c|}{ Aware } & \\
\hline & & Mean & SD & Mean & SD & & Mean & SD & Mean & SD & \\
\hline \multirow[t]{2}{*}{ Age } & & 18.72 & 0.98 & 18.54 & 0.92 & \multirow[t]{2}{*}{$\begin{array}{c}4.33 \\
(<0.001)\end{array}$} & 18.70 & 0.88 & 18.55 & 0.95 & \multirow[t]{2}{*}{$\begin{array}{c}3.09 \\
(0.002)\end{array}$} \\
\hline & & $\mathrm{N}$ & $\%$ & $\mathrm{~N}$ & $\%$ & & $\mathrm{~N}$ & $\%$ & $\mathrm{~N}$ & $\%$ & \\
\hline \multirow[t]{2}{*}{ Gender } & Female & 522 & 47.07 & 587 & 52.93 & \multirow[t]{2}{*}{$\begin{array}{c}17.14 \\
(<0.001)\end{array}$} & 259 & 23.85 & 827 & 76.15 & \multirow[t]{2}{*}{$\begin{array}{l}0.0093 \\
(0.923)\end{array}$} \\
\hline & Male & 591 & 55.97 & 465 & 44.03 & & 231 & 23.67 & 745 & 76.33 & \\
\hline \multirow[t]{4}{*}{ Ethnic groups } & Han & 611 & 44.37 & 766 & 55.63 & \multirow[t]{4}{*}{$\begin{array}{c}87.81 \\
(<0.001)\end{array}$} & 261 & 20.14 & 1,035 & 79.86 & \multirow{4}{*}{$\begin{array}{c}31.87 \\
(<0.001)\end{array}$} \\
\hline & Hui & 165 & 55.56 & 132 & 44.44 & & 80 & 27.78 & 208 & 72.22 & \\
\hline & Tibetan & 199 & 69.34 & 88 & 30.66 & & 90 & 35.43 & 164 & 64.57 & \\
\hline & Other ethnic groups & 138 & 67.65 & 66 & 32.35 & & 59 & 26.34 & 165 & 73.66 & \\
\hline \multirow{3}{*}{$\begin{array}{l}\text { Where } \\
\text { students lived } \\
\text { for the longest } \\
\text { time }\end{array}$} & Village, township & 808 & 58.98 & 562 & 41.02 & \multirow{3}{*}{$\begin{array}{c}98.99 \\
(<0.001)\end{array}$} & 355 & 28.09 & 909 & 71.91 & \multirow{3}{*}{$\begin{array}{c}36.10 \\
(<0.001)\end{array}$} \\
\hline & County & 185 & 44.58 & 230 & 55.42 & & 76 & 19.29 & 318 & 80.71 & \\
\hline & City & 120 & 31.58 & 260 & 68.42 & & 59 & 14.60 & 345 & 85.40 & \\
\hline \multirow{2}{*}{$\begin{array}{l}\text { Single parent } \\
\text { family }\end{array}$} & Yes & 99 & 48.29 & 106 & 51.71 & \multirow{2}{*}{$\begin{array}{c}0.88 \\
(0.348)\end{array}$} & 47 & 25.27 & 139 & 74.73 & \multirow{2}{*}{$\begin{array}{c}0.256 \\
(0.613)\end{array}$} \\
\hline & No & 1,014 & 51.73 & 946 & 48.27 & & 443 & 23.61 & 1,433 & 76.39 & \\
\hline \multirow{4}{*}{$\begin{array}{l}\text { Paternal } \\
\text { education }\end{array}$} & Primary school or below & 347 & 62.86 & 205 & 37.14 & \multirow{4}{*}{$\begin{array}{l}61.06 \\
(<0.001)\end{array}$} & 146 & 28.40 & 368 & 71.60 & \multirow{4}{*}{$\begin{array}{c}35.82 \\
(<0.001)\end{array}$} \\
\hline & Junior middle school & 435 & 52.35 & 396 & 47.65 & & 215 & 27.89 & 556 & 72.11 & \\
\hline & Senior middle school & 191 & 46.47 & 220 & 53.53 & & 74 & 17.58 & 347 & 82.42 & \\
\hline & Above Senior middle school & 140 & 37.74 & 231 & 62.26 & & 55 & 15.45 & 301 & 84.55 & \\
\hline \multirow{4}{*}{$\begin{array}{l}\text { Maternal } \\
\text { education }\end{array}$} & Primary school or below & 518 & 60.16 & 343 & 39.84 & 63.58 & 230 & 27.71 & 600 & 72.29 & 19.83 \\
\hline & Junior middle school & 354 & 50.79 & 343 & 49.21 & $(<0.001)$ & 152 & 23.57 & 493 & 76.43 & $(<0.001)$ \\
\hline & Senior middle school & 137 & 43.49 & 178 & 56.51 & & 67 & 21.41 & 246 & 78.59 & \\
\hline & Above Senior middle school & 104 & 35.62 & 188 & 64.38 & & 41 & 14.96 & 233 & 85.04 & \\
\hline $\begin{array}{l}\text { Relationship } \\
\text { status }\end{array}$ & Previously in a relationship & 267 & 50.86 & 258 & 49.14 & $\begin{array}{c}0.13 \\
(0.939)\end{array}$ & 120 & 23.90 & 382 & 76.10 & $\begin{array}{c}0.65 \\
(0.723)\end{array}$ \\
\hline & In a relationship & 147 & 51.04 & 141 & 48.96 & & 75 & 25.51 & 219 & 74.49 & \\
\hline & Not in a relationship & 699 & 51.70 & 653 & 48.30 & & 295 & 23.30 & 971 & 76.70 & \\
\hline Attitudes on & Sympathetic and want to help & 684 & 46.44 & 789 & 53.56 & 55.89 & 322 & 21.52 & 1,174 & 78.48 & 29.06 \\
\hline patients & Indifferent & 204 & 56.20 & 159 & 43.80 & & 63 & 22.83 & 213 & 77.17 & \\
\hline & Fear and avoidance & 225 & 68.39 & 104 & 31.61 & & 105 & 36.21 & 185 & 63.79 & \\
\hline Total & & 1,113 & 51.41 & 1,052 & 48.59 & & 490 & 23.76 & 1,572 & 76.24 & \\
\hline
\end{tabular}




\begin{tabular}{|c|c|c|c|c|c|c|}
\hline & \multicolumn{2}{|c|}{$\begin{array}{l}\text { Pre- health education } \\
\qquad(\mathrm{N}=2,165)\end{array}$} & \multicolumn{2}{|c|}{$\begin{array}{l}\text { Post- health education } \\
\qquad(\mathrm{N}=2,062)\end{array}$} & \multirow[b]{2}{*}{$x^{2}$} & \multirow[b]{2}{*}{$P$} \\
\hline & Correct cases & $\begin{array}{c}\text { Awareness rate } \\
(\%)\end{array}$ & Correct cases & Awareness rate $(\%)$ & & \\
\hline$Q^{* 1}$ & 1,372 & 63.37 & 1,584 & 76.82 & 90.82 & $<0.001$ \\
\hline Q2 & 646 & 29.84 & 1,159 & 56.21 & 300.14 & $<0.001$ \\
\hline Q3 & 1,519 & 70.16 & 1,758 & 85.26 & 138.12 & $<0.001$ \\
\hline Q4 & 1,575 & 72.75 & 1,699 & 82.40 & 56.29 & $<0.001$ \\
\hline Q5 & 1,328 & 61.34 & 1,666 & 80.80 & 193.49 & $<0.001$ \\
\hline Q6 & 1,434 & 66.24 & 1,757 & 85.21 & 205.48 & $<0.001$ \\
\hline Q7 & 1,807 & 83.46 & 1,931 & 93.65 & 107.04 & $<0.001$ \\
\hline Q8 & 1,321 & 61.02 & 1,489 & 72.21 & 59.40 & $<0.001$ \\
\hline Total & 1,052 & 48.59 & 1,572 & 76.24 & 342.87 & $<0.001$ \\
\hline $\begin{array}{r}{ }^{*} Q 1: \text { Is } \\
\text { Q2:At } \\
m \\
\text { Q3:Ca } \\
\text { Q4:W } \\
\text { Q5: DC } \\
\text { Q6:W } \\
\text { AIDS } \\
\text { Q7: Af } \\
\text { testin } \\
\text { Q8: Are } \\
\text { perso }\end{array}$ & $\begin{array}{l}\text { DS an incurable an } \\
\text { resent, the epidemic } \\
\text { in mode of transmis } \\
\text { you judge whether } \\
\text { people be infected } \\
\text { s insisting on the co } \\
\text { using new drugs (s } \\
\text { fection? } \\
\text { r a high-risk behavic } \\
\text { and counseling? } \\
\text { he rights and intere } \\
\text { s protected by the } c\end{array}$ & $\begin{array}{l}\text { serious infectious dis } \\
\text { of AIDS among youn } \\
\text { sion is male homosex } \\
\text { a person is infected wi } \\
\text { vith AIDS through dail) } \\
\text { rect use of condoms I } \\
\text { ch as methamphetam } \\
\text { r (needle sharing, uns } \\
\text { ts (such as marriage, } \\
\text { untry's laws? }\end{array}$ & $\begin{array}{l}\text { udents in China is } \\
\text { ty, followed by heter } \\
\text { AIDS through appea } \\
\text { e and learning cont } \\
\text { uce the risk of infec } \\
\text { ecstasy, K powder } \\
\text { sex etc.), should p } \\
\text { ployment or enrolm }\end{array}$ & $\begin{array}{l}\text { growing rapidly, and the } \\
\text { rosexuality. Is that correct? } \\
\text { arance? } \\
\text { act? } \\
\text { tion and spread of AIDS? } \\
\text { etc.) increase the risk of } \\
\text { eople actively seek HIV } \\
\text { ent etc.) of HIV-infected }\end{array}$ & & \\
\hline
\end{tabular}

The description of independent variables in the logistic regression models are shown in Supplementary Table 1. Prior to the health education, those who lived in county $(\mathrm{OR}=1.50,95 \% \mathrm{CI}: 1.16-1.94)$ or city $(\mathrm{OR}=2.32,95 \% \mathrm{CI}$ : 1.75-3.08) for the longest time and students who had the paternal education of being above junior middle school $(\mathrm{P}<0.05)$ had positive correlations with the awareness of knowledge on HIV/AIDS prevention and control. While being male freshmen (OR $=0.67,95 \% \mathrm{CI}$ : 0.56 $0.81)$, Tibetan (OR=0.43, 95\%CI: 0.32-0.58) and other ethnic groups (OR=0.47, 95\%CI: 0.34-0.65), and those who were indifferent to $(\mathrm{OR}=0.63,95 \% \mathrm{CI}$ : $0.50-0.81)$ and had the feeling of fear and avoidance $(\mathrm{OR}=0.41$, 95\%CI: 0.31-0.53) on HIV/AIDS patients were negatively associated with the awareness (Table 3).

Post-health education, those who lived in county $(\mathrm{OR}=1.45,95 \% \mathrm{CI}: 1.06-1.98)$ or city $(\mathrm{OR}=1.76,95 \% \mathrm{CI}$ : 1.24-2.49) for the longest time, and students who had paternal education of senior middle school $(\mathrm{OR}=1.50$, 95\%CI: 1.05-2.15) have positive relationships with the awareness. While being Hui (OR=0.71, 95\%CI: 0.520.97 ) and Tibetan (OR=0.54, 95\%CI: 0.39-0.74) and students who had the feeling of fear and avoidance (OR=0.52, 95\%CI: 0.39-0.68) on HIV/AIDS patients were inversely correlated with the awareness (Table 3). 
Table 3 Multiple logistic analyses pre- and post- the health education.

\begin{tabular}{|c|c|c|c|c|c|c|c|}
\hline \multirow[t]{2}{*}{ Variables } & & \multicolumn{3}{|c|}{ Pre- Health education $(\mathrm{N}=2,165)$} & \multicolumn{3}{|c|}{ Post- Health education $(\mathrm{N}=2,062)$} \\
\hline & & Coefficients & $P$-value & $\mathrm{OR}(95 \% \mathrm{Cl})$ & Coefficients & $P$-value & OR $(95 \% \mathrm{Cl})$ \\
\hline Age & & -0.001 & 0.981 & $0.999(0.90,1.12)$ & -0.02 & 0.685 & $0.98(0.87,1.10)$ \\
\hline Gender & Male & -0.40 & $<0.001$ & $0.67(0.56,0.81)$ & 0.01 & 0.918 & $1.01(0.82,1.25)$ \\
\hline \multirow[t]{3}{*}{ Ethnic groups } & Hui & -0.24 & 0.083 & $0.79(0.60,1.03)$ & -0.34 & 0.032 & $0.71(0.52,0.97)$ \\
\hline & Tibetan & -0.84 & $<0.001$ & $0.43(0.32,0.58)$ & -0.62 & $<0.001$ & $0.54(0.39,0.74)$ \\
\hline & Others & -0.76 & $<0.001$ & $0.47(0.34,0.65)$ & -0.26 & 0.132 & $0.77(0.55,1.08)$ \\
\hline \multirow{2}{*}{$\begin{array}{l}\text { Where students lived } \\
\text { for the longest time }\end{array}$} & County & 0.41 & 0.002 & $1.50(1.16,1.94)$ & 0.37 & 0.019 & $1.45(1.06,1.98)$ \\
\hline & City & 0.84 & $<0.001$ & $2.32(1.75,3.08)$ & 0.57 & 0.002 & $1.76(1.24,2.49)$ \\
\hline Single parent family & No & -0.25 & 0.108 & $0.78(0.57,1.06)$ & 0.08 & 0.685 & $1.08(0.75,1.55)$ \\
\hline \multirow{3}{*}{$\begin{array}{l}\text { Paternal } \\
\text { education }\end{array}$} & Junior middle school & 0.26 & 0.042 & $1.29(1.01,1.65)$ & -0.11 & 0.431 & $0.90(0.68,1.18)$ \\
\hline & Senior middle school & 0.35 & 0.025 & $1.42(1.05,1.92)$ & 0.41 & 0.026 & $1.50(1.05,2.15)$ \\
\hline & $\begin{array}{l}\text { Above Senior middle } \\
\text { school }\end{array}$ & 0.41 & 0.041 & $1.51(1.02,2.24)$ & 0.41 & 0.098 & $1.51(0.93,2.45)$ \\
\hline \multirow{3}{*}{$\begin{array}{l}\text { Maternal } \\
\text { education }\end{array}$} & Junior middle school & 0.05 & 0.688 & $1.05(0.83,1.32)$ & -0.05 & 0.715 & $0.95(0.73,1.24)$ \\
\hline & Senior middle school & 0.07 & 0.674 & $1.07(0.78,1.47)$ & -0.26 & 0.169 & $0.77(0.53,1.12)$ \\
\hline & $\begin{array}{l}\text { Above Senior middle } \\
\text { school }\end{array}$ & 0.18 & 0.400 & $1.20(0.79,1.82)$ & -0.11 & 0.693 & $0.90(0.52,1.54)$ \\
\hline \multirow[t]{2}{*}{ Relationship status } & In a relationship & 0.003 & 0.984 & $1.00(0.74,1.36)$ & -0.14 & 0.420 & $0.87(0.62,1.22)$ \\
\hline & Not in a relationship & 0.01 & 0.932 & $1.01(0.81,1.25)$ & -0.03 & 0.815 & $0.97(0.75,1.25)$ \\
\hline \multirow{2}{*}{$\begin{array}{l}\text { Attitude on HIV/AIDS } \\
\text { patients }\end{array}$} & Indifferent attitude & -0.46 & $<0.001$ & $0.63(0.50,0.81)$ & -0.13 & 0.417 & $0.88(0.64,1.20)$ \\
\hline & Fear and avoidance & -0.90 & $<0.001$ & $0.41(0.31,0.53)$ & -0.66 & $<0.001$ & $0.52(0.39,0.68)$ \\
\hline
\end{tabular}

\section{Discussion}

This preliminary study explored the awareness regarding HIV/AIDS prevention and control before and after a health education intervention among first year university students in China's Tibetan area. The awareness rate increased significantly from $48.59 \%$ to $79.24 \%$ after the students received education and within each of the eight questions (see Table 2) of the questionnaire. The figure after health education was higher than that in Pakistan ${ }^{30}$, Ethiopia $(59.6 \%)^{15}$, and in Beijing, China $(27.7 \%)^{31}$. The differences among studies are likely due to the use of various assessment tools, and cultural norms ${ }^{32}$. The significantly positive effects of related health education on HIV/AIDS knowledge have also been frequently identified in previous studies among university students conducted in other countries or regions, such as in Indonesia ${ }^{33}$, the United States ${ }^{34,35}$ and Turkey ${ }^{37}$.

Post health education, Hui and Tibetan students were less likely to be aware of HIV/AIDS prevention and control and related knowledge compared to the Han students, which could be partly attributed to cultural factors, such as language barriers in getting access to HIV/AIDS-related education ${ }^{26}$. Most Tibetan and Hui students are religious, which may delay the age of having sexual intercourse and decrease the propensity to engage in sexual intercourse ${ }^{38}$. Female students were more knowledgeable than their male counterparts prior to the health education, which is consistent with some of the previously published studies from Malaysia ${ }^{39}$ and the United States ${ }^{40}$, but is not in agreement with some other studies which showed males were more knowledgeable than female students ${ }^{41,42}$. However, posthealth education, gender differences were not found in our study which is similar to a study in Ajman ${ }^{43}$.

Students who had lived for the most part of their lives in a village were less likely to be aware of HIV/AIDS prevention and control related knowledge than those lived mostly in a county or city, which were identified both pre- and post- health education. Similarly, it has identified that urban participants scored higher on HIV/ AIDS prevention-related knowledge compared to rural participants in studies conducted in Beijing and Nanjing of China ${ }^{44}$, as well as in some other countries, such as Jamaica ${ }^{45}$ and Malaysia. ${ }^{39}$ Education and health-related information and services are more accessible in the developed areas compared to the geographically vulnerable regions in China ${ }^{46,47}$. Accordingly, HIV/AIDS related education and prevention programs in China should be implemented based on the needs and features of specific areas ${ }^{44}$.

We also found that students who had paternal education of senior middle school had positive relationships with the awareness on HIV/AIDS related knowledge, 
while we did not identify the role of maternal education. Previous studies have shown that parents with higher education levels were more knowledgeable in general communication and HIV/AIDS knowledge, and fathers had higher sexual related knowledge than mothers ${ }^{48}$, which could partly help to explain our findings. The moderating effects of paternal education level between the residence of longest duration and awareness is still unknown and should be explored in further studies.

Most of the students in our study showed a sympathetic attitude and wanted to help the HIV/AIDS patients especially after receiving the health education. Several studies have indicated that the students' attitudes on HIV/AIDS patients were positively associated with their awareness ${ }^{49,50}$, which were confirmed in our study. A study conducted in an Irish university reported that nearly $50 \%$ of the students were willing to be involved in social volunteer work with HIV/AIDS patients ${ }^{51}$. It also showed that students with higher education levels had an overall positive attitude on many aspects of HIV/AIDS ${ }^{41,52}$.

Our study showed that the awareness rate increased significantly after the health intervention program, hence educational departments and university administrators should promote this health education program regarding the HIV/AIDS related knowledge (which was part of a pilot HIV/AIDS prevention and controlling program launched by the China's Ministry of Education), to help college students to engender positive attitudes towards safe sex and improve their reproductive health.

There were some limitations in our study. First, only first year students from one university rather than multiple centers were included, so the findings should be interpreted with caution when generalized to university students in other places. Second, students were not questioned regarding their sexual experience, which might have an influence on their HIV/AIDS awareness. In addition, since the health education lectures were not given in Tibetan language, their effects on the Tibetan students maybe diluted. Dissemination of health education in different languages should be one of the primary concerns for future studies. Lastly, we totally followed the principle of voluntarism, which could partly lead to the low response rates in this study.
This research opens multiple avenues for future study. The first is taking a longitudinal approach in which participants are followed up 1 -month and 1 year after initial participation. In these studies one could examine their current sexual activities to see if the education has had an impact and also their attitudes towards HIV/AIDS. It would also be good to run this study with students at high school level (age 16-18) so that one could see if there is an impact of administering the education intervention at an earlier age. A final avenue of research could examine the link between religiosity, knowledge of HIV/AIDS and sexual behaviours.

\section{Conclusion}

Awareness of knowledge on HIV/AIDS prevention and control among university first year students improved greatly after receiving health education lectures. Hui and Tibetan students, those who were raised in less developed areas and those who have negative attitudes on HIV/AIDS patients were less knowledgeable. Due to the importance of HIV/AIDS prevention and control and its impact, effective measures and programs should be taken by the government and education department, so as to set health education as a regular part of students' curriculum.

\section{Acknowledgements}

We thank Yang Song, Yan Xuan, YunXia Li, JinZhao Xie and YuXia Zhang from Medical College of Qinghai University for their hard work in collecting data.

\section{Ethical approval}

This study was approved by The Ethic Committee of Medical College of Qinghai University (NO: QHMC2017-00003-PH).

\section{Funding}

This study was supported by the "Chunhui" Project of Ministry of Education of China (NO: Z2017050) and The Qinghai Province Government on the Plan of Thousands of High Level of Innovative Talents.

\section{Competing interests}

None.

\section{References}

1. GBD 2016 Disease and Injury Incidence and Prevalence Collaborators. Global, regional, and national incidence, prevalence, and years lived with disability 
for 328 diseases and injuries for 195 countries, 1990 2016: a systematic analysis for the Global Burden of Disease Study 2016. Lancet (London, England). Sep 16 2017;390(10100)1211-1259.

2. UNAIDS. Global HIV \& AIDS statistics - 2019 fact sheet. 2019.

3. Chinese Center for Disease Control and Prevention. Number of HIV infections, number of cases, deaths and routes of transmission in China. 2018.

4. Sawyer RG, Moss DJ. Sexually transmitted diseases in college men: a preliminary clinical investigation. Journal of American College Health. Nov 1993;42(3):111-115.

5. Anwar M, Sulaiman SA, Ahmadi K, Khan TM. Awareness of school students on sexually transmitted infections (STIs) and their sexual behavior: a cross-sectional study conducted in Pulau Pinang, Malaysia. BMC Public Health. Jan 30 2010;10:47.

6. Ware E, Tura G, Alemu T, Andarge E. Disparities in risky sexual behavior among khat chewer and nonchewer college students in Southern Ethiopia: a comparative cross-sectional study. BMC Public Health. Apr 27 2018;18(1):558.

7. Yang XH, Yuan S, Zhang R, et al. Risky Sexual Behaviors and Associated Factors Among College Students in Lusaka, Zambia. Archives of Sexual Behavior. Jul 152019. 8. Sun X, Liu X, Shi Y, Wang Y, Wang P, Chang C. Determinants of risky sexual behavior and condom use among college students in China. AIDS Care. 2013;25(6):775-783.

9. Zak-Place J, Stern M. Health belief factors and dispositional optimism as predictors of STD and HIV preventive behavior. Journal of the International AIDS Society. Mar-Apr 2004;52(5):229-236.

10. Tapert SF, Aarons GA, Sedlar GR, Brown SA. Adolescent substance use and sexual risk-taking behavior. Journal of Adolescent Health. Mar 2001;28(3):181-189. 11. Chambers LA, Rueda S, Baker DN, et al. Stigma, HIV and health: a qualitative synthesis. BMC Public Health. Sep 3 2015;15:848.

12. DiClemente RJ, Zorn J, Temoshok L. Adolescents and AIDS: a survey of knowledge, attitudes and beliefs about AIDS in San Francisco. American Journal of Public Health. Dec 1986;76(12):1443-1445.

13. Oppong AK, Oti-Boadi M. HIV/AIDS knowledge among undergraduate university students: implications for health education programs in Ghana. African bealth sciences. Jun 2013;13(2):270-277.

14. Kim HY, Park M, Lee E. A cross-sectional survey of relationships between sexual knowledge, sexual attitudes, and reproductive health behaviour among female university students. Contemporary Nurse. Dec 2018;54(6):640-650.

15. Ayalew M, Nigatu D, Sitotaw G, Debie A. Knowledge and attitude towards sexual and reproductive health rights and associated factors among Adet Tana Haik College students, Northwest Ethiopia: a cross-sectional study. BMC Research Notes. Feb 12 2019;12(1):80. 16. Halstead V, Williams JR, Gonzalez-Guarda R. College Students' Perspectives on Campus Health Centers as a Sexual Assault Resource: A Qualitative Analysis. Violence and victims. Feb 1 2018;33(1):109-125.

17. Kalichman SC, Rompa D. Functional health literacy is associated with health status and health-related knowledge in people living with HIV-AIDS. JAIDS Journal of Acquired Immune Deficiency Syndromes. Dec 1 2000;25(4):337-344.

18. Duh E, Medina SP, Coppersmith N, Adjei N, Roberts MB, Magee S. Sex Ed by Brown Med: A Student-Run Curriculum and Its Impact on Sexual Health Knowledge. Family Medicine. Nov 2017;49(10):785-788. 19. Sengupta S, Banks B, Jonas D, Miles MS, Smith GC. HIV interventions to reduce HIV/AIDS stigma: a systematic review. AIDS and Behavior. Aug 2011;15(6):10751087.

20. Navaratna S, Kanda K, Dharmaratne SD, et al. Awareness and attitudes towards HIV/AIDS among residents of Kandy, Sri Lanka. AIDS Care. 2015;27(3):387-391.

21. Hamid Albujeer AN, Shamshiri AR, Taher A. HIV/ AIDS awareness among Iraqi medical and dental students. Journal of International Society of Preventive and Community Dentistry. Sep-Oct 2015;5(5):372-376.

22. Oyeyemi YA, Abdulkarim A, Oyeyemi BO. The influence of knowledge and sociodemographics on AIDS perception and sexual practices among secondary school students in Nigeria. African Health Sciences. Aug 2011;11 Suppl 1:S67-76.

23. Siuki HA, Peyman N, Vahedian-Shahroodi M, Gholian-Aval M, Tehrani H. Health Education Intervention on HIV/AIDS Prevention Behaviors among Health Volunteers in Healthcare Centers: An Applying the Theory of Planned Behavior. Journal of Social Service Research. 2019/08/08 2019;45(4):582-588.

24. Adamczyk A, Hayes BE. Religion and sexual behaviors: Understanding the influence of Islamic cultures and religious affiliation for explaining sex outside of marriage. American Sociological Review. 2012;77(5):723746.

25. Orgocka* A. Perceptions of communication and education about sexuality among Muslim immigrant girls in the US. Sex Education. 2004;4(3):255-271. 
26. Wang S, Keats D. Developing an innovative cross-cultural strategy to promote HIV/AIDS prevention in different ethnic cultural groups of China. AIDS Care. Oct 2005;17(7):874-891.

27. Gao X, Wu Y, Zhang Y, et al. Effectiveness of school-based education on HIV/AIDS knowledge, attitude, and behavior among secondary school students in Wuhan, China. PloS One. 2012;7(9):e44881.

28. Thanavanh B, Harun-Or-Rashid M, Kasuya H, Sakamoto J. Knowledge, attitudes and practices regarding HIV/AIDS among male high school students in Lao People's Democratic Republic. Journal of the International AIDS Society. Mar 11 2013;16:17387.

29. Jin SS. Development, Application and Evaluation of AIDS Warning Education Scale and Curriculum for Young Students (In Chinese) [PhD], Chinese Center for Disease Control and Prevention; 2017.

30. Rehan M, Waheed U, Sarwar M, Arshad M, Satti HS, Zaheer HA. Knowledge, attitude, practices and awareness regarding HIV/AIDS among university students of Islamabad and Rawalpindi, Pakistan. Annals of PIMS ISSN. 2016;1815:2287.

31. Xie XW, Kang J. Sexual behavior and its influencing factors among college students in Beijing (In Chinese). Chinese School of Public Health. 2015;36(1):128-131.

32. Reddy P, Frantz J. HIV/AIDS knowledge, behaviour and beliefs among South African university students. SAHARA-J: Journal of Social Aspects of HIVI AIDS. 2011;8(4):166-170.

33. Husaini RP, Saputra M. The Effects of Health Education Toward HIV/AIDS Knowledge and Attitude on Banjarbaru Midwife Academy Students 2016. Indian Journal of Public Health Research \& Development. 2017;8(8):332-336.

34. Goldsberry J, Moore L, MacMillan D, Butler S. Assessing the effects of a sexually transmitted disease educational intervention on fraternity and sorority members' knowledge and attitudes toward safe sex behaviors. Journal of the American Association of Nurse Practitioners. Apr 2016;28(4):188-195.

35. Tung WC, Serratt TD, Lu M. Evidence-based HIV pilot program for Chinese college students: Differences by gender. Nursing \& Health Sciences. Jun 2015;17(2):263268.

36. Lin YJ, Lee CH, Chang CC, Lin CH. Evaluation of a Video-Based Intervention to Promote Condom Use Among College Students in Taiwan. Studies in Health Technology and Informatics. 2016;226:101-104.

37. Ergene T, Çok F, Tümer A, Ünal S. A Controlled-Study of Preventive Effects of Peer Education and Single-Session Lectures on HIV/AIDS
Knowledge and Attitudes among University Students in Turkey. AIDS Education and Prevention. 2005/06/01 2005;17(3):268-278.

38. Nicholas L, Durrheim K. Religiosity, Aids, and Sexuality Knowledge, Attitudes, Beliefs, and Practices of Black South-African First-Year University Students. Psychological Reports. 1995;77(3):1328-1330.

39. Wong LP, Chin CK, Low WY, Jaafar N. HIV/ AIDS-Related Knowledge Among Malaysian Young Adults: Findings From a Nationwide Survey. Journal of the International AIDS Society. Jun 24 2008;10(6):148.

40. Fisher JD, Misovich SJ. Evolution of college students' AIDS-related behavioral responses, attitudes, knowledge, and fear. AIDS Education and Prevention. Winter 1990;2(4):322-337.

41. Ganczak M, Barss P, Alfaresi F, Almazrouei S, Muraddad A, Al-Maskari F. Break the silence: HIV/AIDS knowledge, attitudes, and educational needs among Arab university students in United Arab Emirates. Journal of Adolescent Health. Jun 2007;40(6):572.e571-578.

42. Abiona T, Balogun J, Yohannes E, et al. HIV/AIDS knowledge, perception of knowledge and sources of information among university students in USA, Turkey, South Africa and Nigeria. Health Education Journal. 2014;73(6):755-767.

43. Haroun D, El Saleh O, Wood L, Mechli R, Al Marzouqi N, Anouti S. Assessing Knowledge of, and Attitudes to, HIV/AIDS among University Students in the United Arab Emirates. PloS One. 2016;11(2):e0149920.

44. Li X, Lin C, Gao Z, et al. HIV/AIDS knowledge and the implications for health promotion programs among Chinese college students: geographic, gender and age differences. Health Promotion International. Sep 2004;19(3):345-356.

45. Warren C. Geographical variations in AIDS knowledge and attitude among adolescent girls of Jamaica. AIDS Education and Prevention. Aug 1999;11(4):364-372. 46. Hu R, Dong S, Zhao Y, Hu H, Li Z. Assessing potential spatial accessibility of health services in rural China: a case study of Donghai County. International Journal for Equity in Health. May 20 2013;12:35.

47. Gao Y, He QS, Liu YL, Zhang LY, Wang HF, Cai EX. Imbalance in spatial accessibility to primary and secondary schools in china: Guidance for education sustainability. Sustainability. 2016;8(12):1236.

48. Gallegos EC, Villarruel AM, Gomez MV, Onofre DJ, Zhou Y. Research brief: sexual communication and knowledge among Mexican parents and their adolescent children. Journal of the Association of Nurses in AIDS Care. Mar-Apr 2007;18(2):28-34.

49. Jahanfar S, SANN LM, Rampal L. Sexual behavior, 
knowledge and attitude of non-medical university students towards HIV/AIDS in Malaysia. Shiraz E-Medical Journal. 2010;11(3):126-129.

50. Santos VP, Coelho MTÁD, Macário EL, Oliveira TCDS. Is there a relationship between students' knowledge of HIV/AIDS ways of transmission and their responses regarding their proximity to people living with HIV/AIDS? Ciencia \& saude coletiva. 2017;22(8):27452752.
51. Choudhary HA, Ali RA, Altaf S. Knowledge, behaviour and attitudes regarding HIV/AIDS among undergraduate students in an Irish university. International Journal of Surgery and Medicine Aug 2015;1(2):58-66.

52. Mkumbo K. Assessment of HIV/AIDS knowledge, attitudes and behaviours among students in higher education in Tanzania. Global Public Health. 2013/12/01 2013;8(10):1168-1179. 